\title{
PEMBELAJARAN KLASIFIKASI KLADOGRAM DENGAN METODE TAKSIMETRI UNTUK MEMPELAJARI KEKERABATAN TANAMAN GENUS TILLANDSIA \& NEOREGELIA
}

\section{(Learning cladogram classification using taximetry method for learning general tillandsia \& neoregelia plant)}

\author{
Fendy Hardian Permana ${ }^{1 *}$, Nurwidodo ${ }^{2}$, Lise Chamisijatin ${ }^{3}$, Siti Zaenab ${ }^{4}$, \\ Yuni Pantiwati ${ }^{5}$, Dwi Sulistiarini ${ }^{6}$ \\ 1,2,3,4,5 Pendidikan Biologi, FKIP, Universitas Muhammadiyah Malang, Indonesia \\ ${ }^{6}$ SMA Negeri 3 Malang, Indonesia \\ *Email: fendy@umm.ac.id \\ *Corresponden Author
}

\begin{abstract}
ABSTRAK
Lingkungan SMAN 3 Malang memiliki konsep taman vertikal, sehingga cocok digunakan tempat pembelajaran outdoor learning dan pembelajaran langsung. Hasil observasi menunjukkan pemanfaatan tanaman untuk media pembelajaran belum optimal. Belum optimalnya disebabkan belum adanya informasi nama ilmiah, deskripsi, dan hubungan kekerabatan tumbuhan. Berdasarkan hal tersebut maka perlu dilakukan inovasi pembelajaran. Penelitian ini bertujuan mendeskripsikan penerapan pembelajaran klasifikasi kladogram dengan metode taksimetri: 1) pemanfaatan tanaman tillandsia \& neoregelia untuk sumber belajar klasifikasi \& kladogram tanaman, 2) jumlah spesies tillandsia \& neoregelia, 3) hubungan kekerabatan tanaman tillandsia \& neoregelia. Penelitian ini merupakan deskriptif dengan metode survey, melalui pembelajaran klasifikasi \& kladogram dengan taksimetri. Teknik analisis data secara deskriptif yaitu identifikasi jenis-jenis tumbuhan menggunakan gambar dan buku kunci determinasi (taksimetri). Hasil menunjukkan bahwa melalui pembelajaran klasifikasi kladogram dengan metode taksimetri diperoleh data sebagai berikut 1) pemanfaatan tanaman dengan ciri morfologi serta persamaan dan perbedaannya menjadi sumber belajar klasifikasi tumbuhan \& pembuatan kladogram berlangsung dengan efektif dimana ditunjukkan dengan siswa terampil dalam melakukan klasifikasi tanaman yang ada di lingkungan sekolah dan terampil membuat kladogram dari kegiatan klasifikasi, 2) terdapat 2 spesies tillandsia yaitu Tillandsia lonantha \& Tillandsia cyanea serta terdapat 1 spesies neoregelia yaitu Neoregelia spectabilis, 3) hubungan kekerabatannya tanaman tersebut satu family yaitu Bromeliaceae.
\end{abstract}

Kata Kunci: Kekerabatan Tillandsia \& Neoregelia; Kladogram; Taksimetri; Pembelajaran Klasifikasi

\begin{abstract}
The environment of State Senior High School (SMAN) 3 Malang employed a concept of vertical garden, making the environment suitable for outdoor learning and direct learning. Observation results indicated the use of plants for learning media is not optimal due to the lack of information on scientific names, descriptions, and relationships of plants. Based on the observation, it was necessary to design a learning innovation. This research aimed to describe the application of Cladogram classification learning with the Asymmetric method: 1) the utilization of Tillandsia \& Neoregelia plants for the source of plant classification \& Cladogram learning, 2) the number of Tillandsia \& Neoregelia species, 3) the relationship between Tillandsia \& Neoregelia plants. This research employed a descriptive survey method through learning classification \& Cladograms with Asymmetry. The descriptive data analysis technique defined the identification of plant types using pictures and key books of determination (asymmetry). The results showed that through the learning of cladogram classification with the asymmetry method, the following data were obtained: 1) the use of plants with morphological characteristics and similarities and differences became the source of learning for plant classification and making cladograms effectively indicated by students performance in doing
\end{abstract}


the classification of plants in the school environment and making cladograms from classification activities, 2) there were two species of tillandsia namely Tillandsia lonantha \& Tillandsia cyanea, and there was one neoregelia species namely Neoregelia spectabilis, 3) familial relationship of the plant is one family namely Bromeliaceae.

Keywords: Cladogram; Kinship Tillandsia \& Neoregelia; Taximetry; Classification Learning

Copyright (c) 2020 Permana et al This is an open access article under the $\underline{\mathrm{CC}-\mathrm{BY}}$ license

\section{Check for updates}

How to cite: Permana, F., Nurwidodo, N., Chamisijatin, L., Zaenab, S., Pantiwati, Y., \& Sulistiarini, D. (2020). Pembelajaran Klasifikasi Kladogram Dengan Metode Taksimetri Untuk Mempelajari Kekerabatan Tanaman Genus Tillandsia \& Neoregelia. JINoP (Jurnal Inovasi Pembelajaran), 6(1). doi:https://doi.org/10.22219/jinop.v6i1.7084

\section{PENDAHULUAN}

Pemanfaatan lingkungan sekolah SMAN 3 Malang cukup asri dengan konsep taman vertikal karena keterbatasan lahannya. Berbagai tanaman hias seperti kaktus, tillandsia, dan bromilia dihadirkan di setiap sudut ruang yang menyebabkan suasana lingkungan menjadi nyaman sekalipun tidak luas. Sekolah ini pernah mendapatkan penghargaan sebagai pemenang Adiwiyata pada tahun 2015.

Lingkungan sekolah dapat dimanfaatkan sebagai salah satu sumber belajar yang dapat dioptimalkan untuk pencapaian proses dan hasil pendidikan yang berkualitas bagi siswa. Pemanfaatan lingkungan sebagai sumber belajar akan semakin memperkaya wawasan dan pengetahuan siswa. Siswa belajar tidak dibatasi oleh dinding kelas, selain itu kebenaran pengetahuan diperoleh akan lebih akurat, sebab siswa dapat mengalami secara langsung dan dapat mengoptimalkan potensi panca inderanya untuk berkomunikasi dengan lingkungan tersebut. Lingkungan sekitar juga dapat dijadikan media pengajaran dimana siswa memperoleh pengalaman langsung yang tidak mudah untuk dilupakan. Banyak nilai dan manfaat yang dapat diraih dari lingkungan sebagai sumber belajar dimana berbagai konsep dapat dipelajari melalui pemanfaatan lingkungan. Namun untuk mengoptimalkan pemanfaatan lingkungan sebagai sumber belajar diperlukan adanya kreativitas dan inovasi dari para guru.

Hasil observasi awal diperoleh informasi bahwa tumbuhan yang hidup di sekitar SMAN 3 Malang belum teridentifikasi secara baik dan benar. Pemanfaatan tumbuhan yang hidup di lingkungan sekolah sebagai media pembelajaran masih belum optimal. Hal ini disebabkan karena belum ada informasi tentang nama ilmiah dan deskripsi tumbuhan tersebut. Untuk itu perlu dilakukan identifikasi dengan harapan hasilnya dapat dimanfaatkan sebagai sumber belajar bagi siswa. Keberadaan tumbuh-tumbuhan di lingkungan sekolah berpotensi untuk dapat dimanfaatkan sebagai media yang menunjang kegiatan pembelajaran, baik di dalam maupun diluar kelas.

Penelitian tentang pemanfaatan lingkungan sebagai sumber belajar pernah dilakukan oleh tiga peneliti terdahulu yaitu: (1) Arrijani, (2003) dalam penelitian keanekaragaman hayati hasil inventarisasi tumbuhan berpotensi tanaman hias di Gunung Sari Singkawang dalam bentuk buku saku. (2) Sihvonen \& Kaila, (2004) dalam penelitian memanfaatkan lingkungan di sekitar sekolah (khususnya kebun sekolah) sebagai pusat sumber belajar. (3) Astirin, (2000) dalam penelitian keanekaragaman

Fendy Hardian Permana, Nurwidodo, Lise Chamisijatin, Siti Zaenab, Yuni Pantiwati, Dwi Sulistiarini, Pembelajaran Klasifikasi Kladogram Dengan Metode Taksimetri Untuk Mempelajari Kekerabatan Tanaman Genus Tillandsia \& Neoregelia 
tumbuhan di lingkungan sekolah dan implementasinya dalam pembelajaran di SMPN 2 Palu. Ketiga penelitian terdahulu inilah, yang menjadi acuan peneliti untuk melakukan penelitian tentang jenis-jenis tumbuhan di sekitar sekolah dan pengembangannya sebagai media pembelajaran. Penelitian ini lebih mengkhususkan jenis tumbuhan di sekitar sekolah yang nantinya dapat dipergunakan oleh siswa sebagai media pembelajaran biologi dalam mempelajari keanekaragaman hayati dan klasifikasi.

Keanekaragaman tumbuhan yang tersedia di sekolah menarik perhatian untuk dimanfaatkan sebagai sumber belajar, khususnya tentang keanekaragaman tumbuhan dan klasifikasinya. Dengan memanfaatkan tumbuhan yang terdapat di sekitar sekolah ini pembelajaran klasifikasi tumbuhan menjadi sangat relevan. Dengan tersedianya beranekaragam spesies dan jenis tumbuhan maka ini merupakan obyek belajar klasifikasi tumbuhan yang menarik dan potensial. Aspek potensial yang dapat dikembangkan diantaranya adalah untuk mempelajari kesamaan ciri dan perbedaan karakteristiknya serta mengungkap hubungan kekerabatan yang terdapat diantaranya.

Berdasarkan uraian pada latar belakang yang berkaitan dengan berbagai jenis tumbuhan di sekitar sekolah dan potensi pemanfaatannya sebagai sumber belajar, maka perlu dilakukan penelitian tentang jenis-jenis tumbuhan di sekitar sekolah SMAN 3 Malang dan pengembangannya sebagai media pembelajaran biologi. Penelitian ini bertujuan untuk mendeskripsikan penerapan pembelajaran klasifikasi kladogram dengan metode taksimetri guna mendapatkan data tentang 1) pemanfaatan tanaman tillandsia \& neoregelia untuk sumber belajar klasifikasi \& kladogram tanaman, 2) jumlah spesies tillandsia \& neoregelia, 3) hubungan kekerabatan tanaman tillandsia \& neoregelia.

Pembelajaran klasifikasi kladogram dengan metode taksimetri memiliki keunggulan dimana pembelajaran ini siswa bisa secara aktif mengkonstruksi konsep tentang klasifikasi makhluk hidup dengan metode taksimetri menggunakan media tanaman yang ada di sekolah. Kebaharuan dari pembelajaran ini yaitu siswa tidak hanya melakukan klasifikasi makhluk hidup saja dengan metode taksimetri, tetapi siswa juga membuat hubungan kekerabatan/kladogram dari data hasil klasifikasi yang dilakukan siswa. Pembelajaran selama ini yang dilakukan oleh guru tidak mengaitkan KD materi klasifikasi dengan KD materi kladogram, sehingga siswa mendapatkan konsepnya secara terpisah. Dengan pembelajaran klasifikasi kladogram dengan metode taksimetri ini secara tidak langsung materi yang disampaikan guru sudah menggabungkan antara KD materi klasifikasi dengan KD materi kladogram, sehingga siswa mendapatkan konsep materinya secara utuh.

\section{METODE}

a. Desain dan Metode Penelitian

Penelitian dilakukan dalam dua tahap yaitu jenis penelitian pada tahap pertama yaitu penelitian deskriptif. Adapun metode yang digunakan adalah survey. Penelitian tahap kedua merupakan jenis penelitian pengembangan. Obyek yang dikembangkan dalam penelitian ini adalah spesimen jenis-jenis tumbuhan yang diperoleh di sekitar SMAN3 Malang menjadi media pembelajaran biologi.

b. Subyek penelitian

Populasi dalam penelitian ini adalah siswa SMAN 3 Malang. Sampel pada penelitian ini adalah siswa kelas X SMAN 3 Malang. 
c. Waktu dan Tempat

Penelitian ini dilaksanakan di sekitar SMAN 3 Malang pada bulan Juli 2018 sampai bulan Agustus 2018.

d. Metode Pengumpulan Data

Pengumpulan data dilakukan dengan cara observasi siswa yang sedang melakukan pengamatan morfologi kaktus, tillandsia, dan bromilia. Data juga didapat dengan menilai hasil kladogram yang sudah dibuat oleh siswa. Selain itu data juga didapat dari hasil tes pada siswa materi penyusunan kladogram.

\section{e. Tehnik Analisis Data}

Analisis data dilakukan dengan menganalisis hasil observasi siswa dalam melakukan pengamatan morfologi tanaman, menilai hasil kladogram yang sudah dibuat oleh siswa, dan dari hasil tes pada siswa materi penyusunan kladogram.

Hasil pengamatan yang dilakukan oleh siswa akan dianalisis secara deskriptif yaitu identifikasi jenis-jenis tumbuhan menggunakan gambar dan buku kunci determinasi. Setiap jenis tumbuhan dideskripsikan ciri-ciri botani, keadaan habitat dan kedudukannya dalam taksonomi. Data tersebut selanjutnya digunakan untuk pemusatan perhatian pada kaktus, tillandsia, dan bromilia. Tahap ini merupakan tahap identifikasi ciri umum maupun spesifik dari morfologi kaktus, tillandsia, dan bromilia. Data ciri karakteristik dari semua spesies kaktus, tillandsia, dan bromilia digunakan untuk menganalisis perbedaan dan persamaan sifat dan mencari hubungan kekerabatannya dengan menggunakan prosedur taksimetri.

\section{HASIL DAN PEMBAHASAN}

\section{1) Pembelajaran klasifikasi dan kladogram menggunakan tanaman tillandsia \&} neoregelia di lingkungan sekitar sebagai sumber belajar.

Pembelajaran biologi pada siswa kelas X SMA pada KD 3.3 (Menjelaskan prinsip-prinsip klasifikasi makhluk hidup dalam lima kingdom) dan KD 4.3 (Menyusun kladogram berdasarkan prinsip-prinsip klasifikasi makhluk hidup) menunjukkan bahwa siswa diharapkan setelah mempelajari materi pada KD tersebut siswa memiliki potensi memahami klasifikasi makhluk hidup dan terampil dalam menyusun kladogram berdasarkan klasifikasi tersebut. Dalam membekali siswa untuk dapat mencapai KD tersebut maka perlu ada inovasi dari guru bagaimana cara mengajarkan dan menanamkan kompetensi tersebut. Salah satu inovasi yang dapat dilakukan oleh guru adalah dengan menggunakan kegiatan pembelajaran yang kontekstual. Seperti yang dinyatakan oleh Ramadhani, Erman, \& Indah, (2016) proses pembelajaran Ilmu Pengetahuan Alam menekankan pada pemberian pengalaman secara langsung, karena pengalaman langsung bisa memberikan pembelajaran yang bersifat konkrit, sehingga siswa dapat memahami konsep yang sedang dipelajari.

Pembelajaran kontekstual untuk KD 3.3 dan 4.3 adalah dengan cara mengajak siswa mengamati langsung macam-macam tanaman untuk dapat melakukan klasifikasi yang kemudian disusun menjadi kladogram. Berdasarkan hasil identifikasi tanamantanaman yang ada di lingkungan SMAN 3 Malang menunjukkan bahwa tanaman yang paling banyak ditemukan adalah kaktus, tillandsia, dan bromilia. Tanaman yang berjumlah banyak tersebut yang dapat digunakan dalam pembelajaran kontekstual untuk KD 3.3 dan 4.3, sehingga desain pembelajarannya adalah kegiatan pengamatan

Fendy Hardian Permana, Nurwidodo, Lise Chamisijatin, Siti Zaenab, Yuni Pantiwati, Dwi Sulistiarini, Pembelajaran Klasifikasi Kladogram Dengan Metode Taksimetri Untuk Mempelajari Kekerabatan Tanaman Genus Tillandsia \& Neoregelia 
langsung dengan menggunaka obyek yang akan diklasifikasi serta dibuat kladogram adalah tanaman kaktus, tillandsia, \& bromilia. Kegiatan pembelajaran tersebut dapat dibagi menjadi 2 kali pertemuan, dimana pertemuan pertama adalah melakukan pengamatan dan mengklasifikasi tanaman untuk mencapai KD 3.3. Pertemuan kedua adalah melakukan penyusunan kladogram berdasarkan data yang didapat dari pertemuan pertama untuk mencapai KD 4.3.

Pemilihan materi bertujuan untuk memenuhi standar kompetensi yang ditetapkan oleh pemerintah seperti yang dinyatakan oleh Depdiknas, (2006) bahwa materi pembelajaran (instructional materials) berupa pengetahuan, keterampilan, dan sikap yang harus dikuasai peserta didik dalam rangka memenuhi standar kompetensi yang ditetapkan. Materi pembelajaran menempati posisi yang sangat penting dari keseluruhan kurikulum, yang harus dipersiapkan agar pelaksanaan pembelajaran dapat mencapai sasaran. Materi pembelajaran dipilih seoptimal mungkin untuk membantu peserta didik dalam mencapai standar kompetensi dan kompetensi dasar.

Kegiatan pertemuan pertama pada KD 3.3 siswa diajak untuk melakukan kegiatan klasifikasi tanaman kaktus, tillandsia, \& bromilia di lingkungan SMAN 3 Malang dengan metode taksimetri.

Taksimetri merupakan metode untuk menentukan jauh dekatnya suatu hubungan kekerabatan antara dua takson tumbuhan secara kuantitatif dengan menggunakan analisis cluster atau analisis kelompok. Taksimetri masuk pada masa kontemporer. Tujuan taksimetri yaitu untuk meningkatkan objektivitas dalam pengolahan data dari klasifikasi yang diperoleh. Langkah-langkah dalam taksimetri adalah:

1. Pemilihan obyek studi, dilakukan dengan memperhatikan Operasional Taksonomi Unit (OTU). Objek studi yang diamati dapat berupa indiividu, varietas, jenis, dan sebagainya;

2. Pemberian kode pada ciri tumbuhan yang digunakan. Ciri hanya ada dua tingkat yaitu jika karakter dimiliki oleh spesies ditandai dengan angka 1, dan jika tidak dimiliki oleh spesies ditandai dengan angka 0 ;

3. Analisis Kelompok (Cluster Analysis), yaitu pengelompokan OTU yang sama kedalam satu kelompok yang disebut dengan fenon. Setelah itu dilanjutkan dengan penataan secara hierarki dalam bentuk diagram yang disebut dengan dendogram;

4. Diskriminasi, bertujuan untuk menentukan ciri konstan yang dilihat dari nilai terbanyak dengan cara menelaah kembali ciri yang digunakan.

Kegiatan diawali dengan pemberian pengantar awal dari guru model (Gambar 1.a) kepada siswa. Guru model memberikan arahan apa yang akan dilakukan oleh siswa pada kegiatan pembelajaran dan membimbing siswa menuju lingkungan luar kelas untuk melakukan pengamatan dan klasifikasi (Gambar 1.b). Siswa kemudian melakukan pengamatan dengan mengumpulkan tanaman-tanaman yang ada di lingkungan sekolah terlebih dahulu yang termasuk tanaman kaktus, tillandsia, \& bromilia menjadi satu agar nantinya mudah untuk melakukan pengamatan (Gambar 2). 


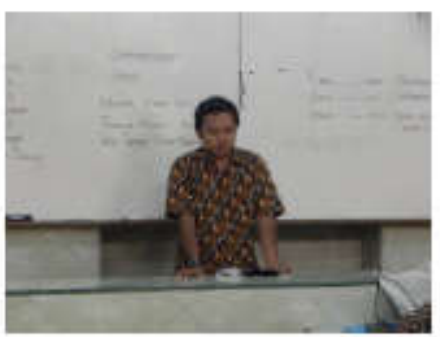

a

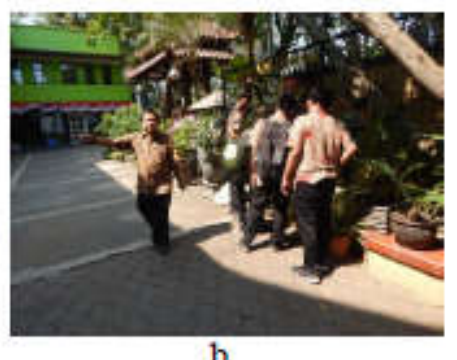

$\mathrm{b}$

Gambar 1. a) guru model memberikan arahan pada siswa. b) guru model membimbing siswa menuju lingkungan luar kelas

Siswa dalam melakukan kegiatan pengamatan dilakukan secara berkelompok. Kelompok dibagi menjadi ada 6 kelompok dimana setiap kelompok melakukan pengamatan pada tanaman kaktus, tillandsia, \& bromilia. Kelompok yang melakukan pengamatan pada tanaman tillandsia dapat dilihat pada Gambar 3. Kelompok yang melakukan pengamatan pada tanaman bromilia dapat dilihat pada Gambar 4. Kelompok yang melakukan pengamatan pada tanaman kaktus dapat dilihat pada Gambar 5.

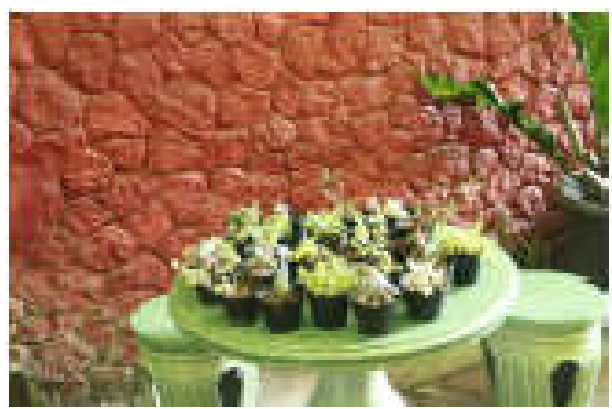

Gambar 2. Tanaman kaktus yang dikumpulkan menjadi satu
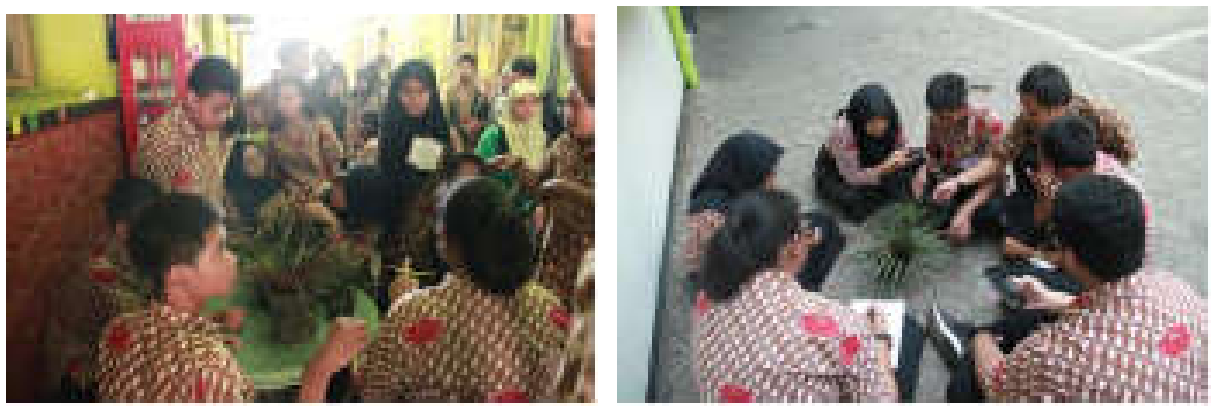

Gambar 3. Kelompok melakukan pengamatan tanaman tillandsia

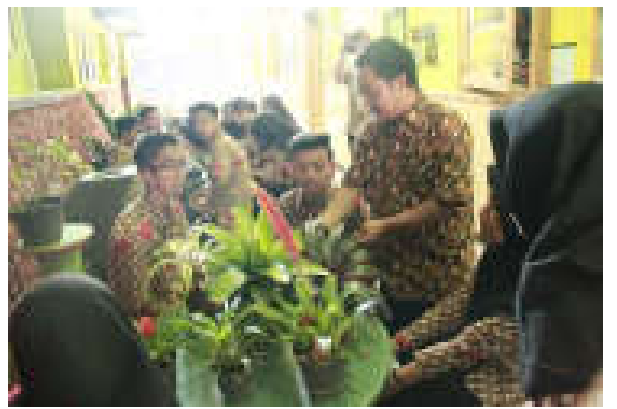

Gambar 4. Kelompok melakukan pengamatan tanaman bromilia

Fendy Hardian Permana, Nurwidodo, Lise Chamisijatin, Siti Zaenab, Yuni Pantiwati, Dwi Sulistiarini, Pembelajaran Klasifikasi Kladogram Dengan Metode Taksimetri Untuk Mempelajari Kekerabatan Tanaman Genus Tillandsia \& Neoregelia 


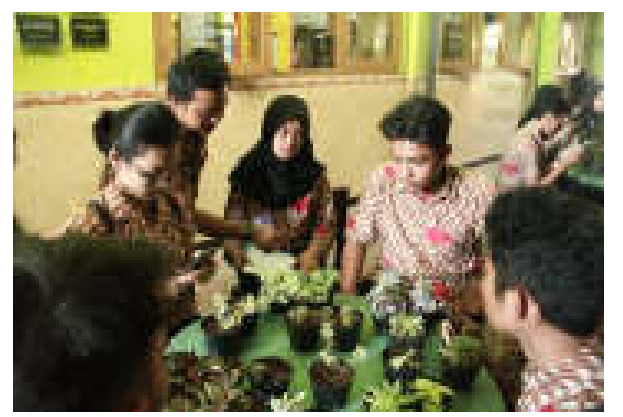

Gambar 5. Kelompok melakukan pengamatan tanaman kaktus

Siswa dalam melakukan pengamatan dan klasifikasi menggunakan 3 langkah cara yaitu memfoto tanaman sebagai dokumentasi (Gambar 6.a), mencari informasi di internet dan membandingkan dengan temuan informasi morfologi tanaman yang didapat (Gambar 6.b), dan melakukan pencatatan terhadap informasi yang telah ditemukan tersebut (Gambar 6.c). Siswa setelah melakukan pengamatan dan klasifikasi, kemudian guru model memberikan penguatan kepada siswa dan mengarahkan pada siswa bagaimana penyusunan kladogram berdasarkan data klasifikasi yang telah didapatkan (Gambar 7.).

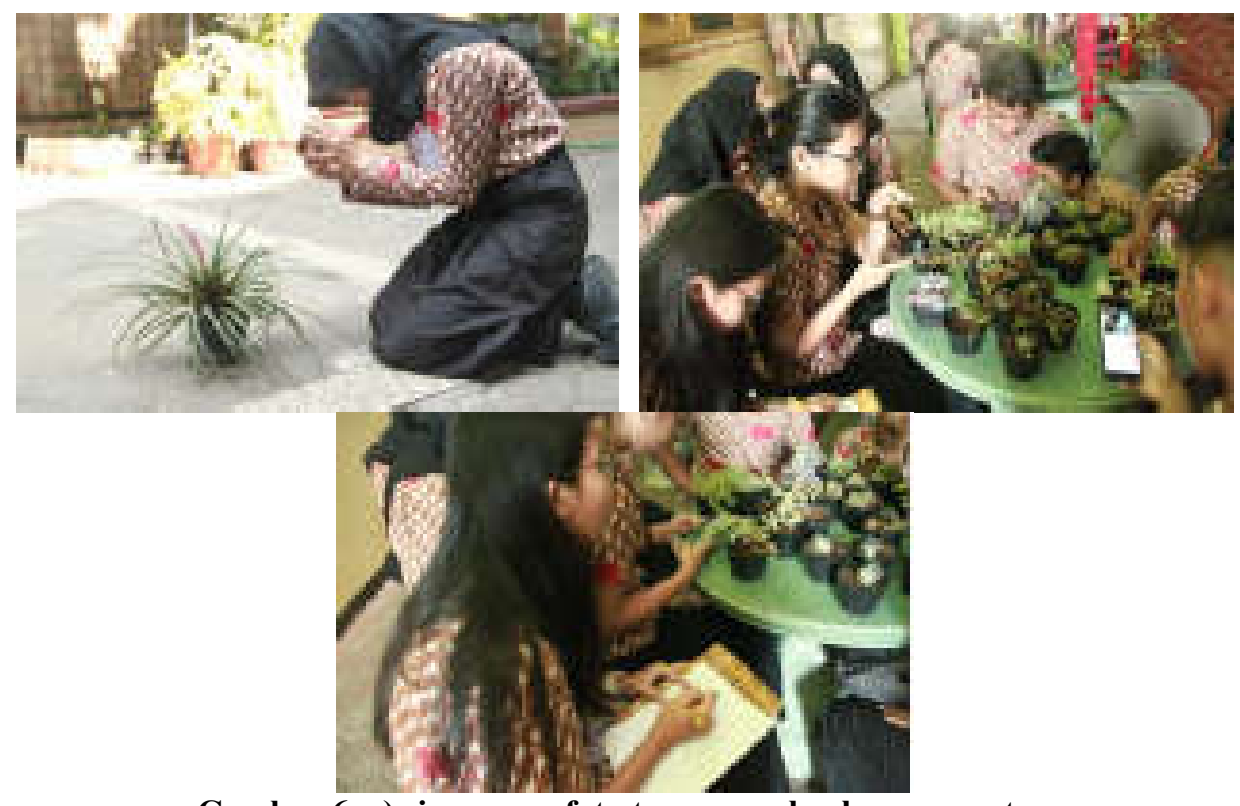

Gambar 6. a) siswa memfoto tanaman obyek pengamatan

b) siswa mencari informasi tentang tanaman di internet c) siswa mencatat informasi yang di dapat
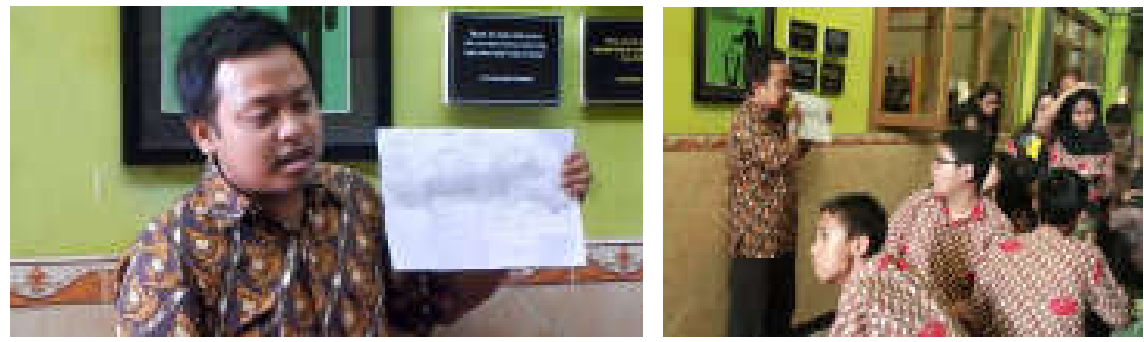

Gambar 7. Guru model memberikan pengarahan untuk penyusunan kladogram di pertemuan berikutnya

JINoP (Jurnal Inovasi Pembelajaran),Volume 6, Nomor 1, Mei 2020, hal 28-40 
Kegiatan pertemuan kedua siswa belajar tentang KD 4.3 yaitu dimana siswa belajar untuk melakukan penyusunan kladogram berdasarkan data klasifikasi tumbuhan kaktus, tillandsia, \& bromilia yang telah didapatkan pada pertemuan pertama. Kegiatan diawali dengan guru model memberikan pengantar dan arahan terkait kegiatan pembelajaran yang akan dilakukan oleh siswa (Gambar 8). Siswa bekerja secara mandiri membuat kladogram sesuai arahan dari guru model dengan menggunakan data klasifikasi tanaman pada pertemuan pertama (Gambar 9). Siswa melakukan konsultasi kepada guru model terkait kladogram yang sedang mereka kerjakan (Gambar 10). Siswa kemudian memadukan hasil yang sudah dikerjakannya dengan yang dikerjakan oleh temannya (Gambar 11).
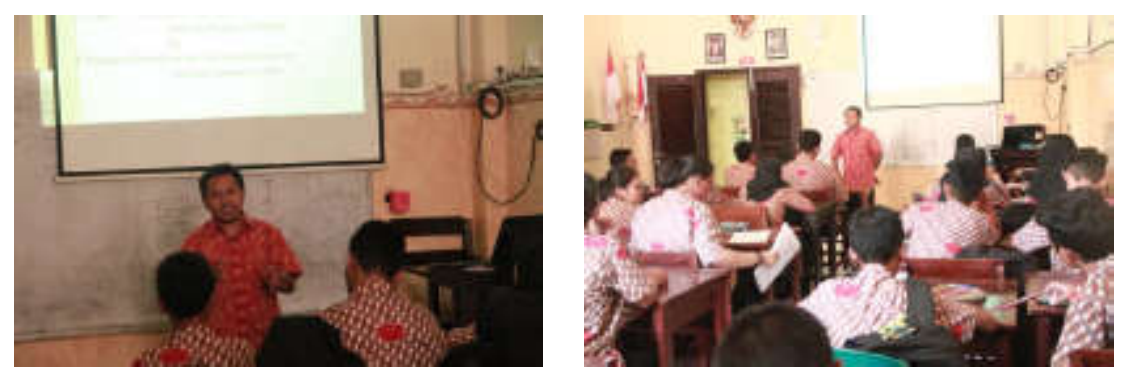

Gambar 8. Guru model memberikan pengantar dan arahan terkait kegiatan pembelajaran

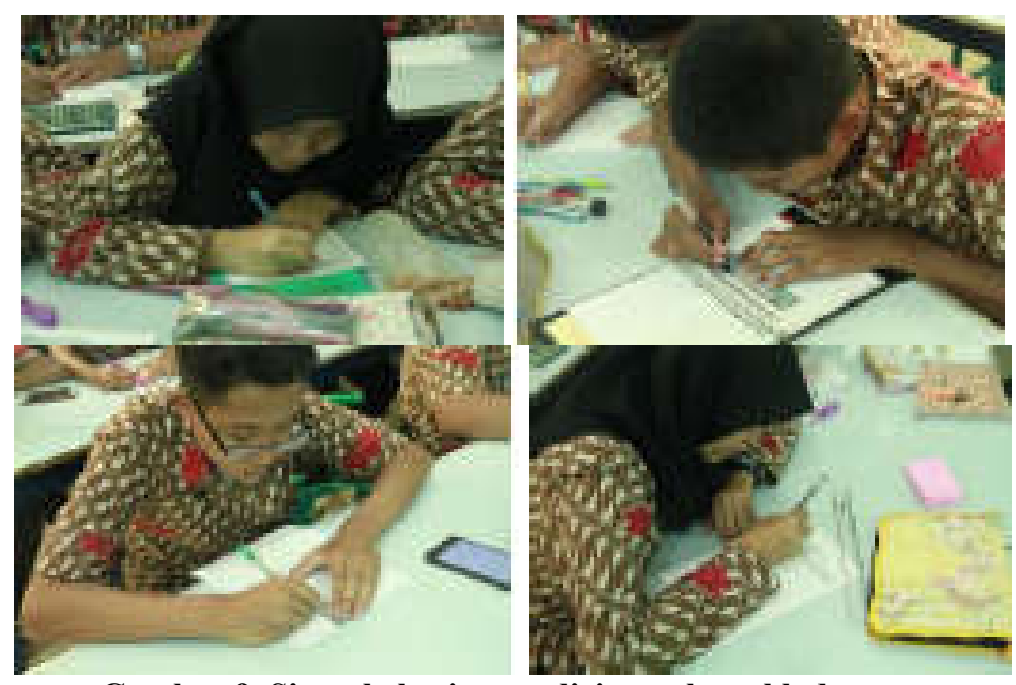

Gambar 9. Siswa bekerja mandiri membuat kladogram
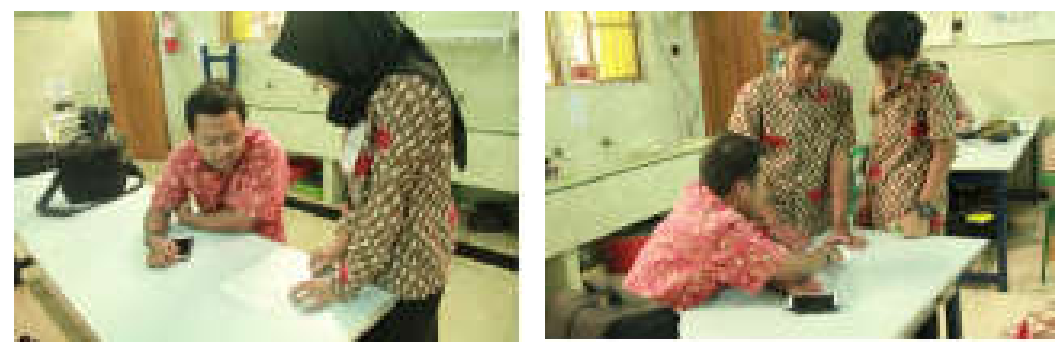

Gambar 10. Siswa melakukan konsultasi pada guru model

Fendy Hardian Permana, Nurwidodo, Lise Chamisijatin, Siti Zaenab, Yuni Pantiwati, Dwi Sulistiarini, Pembelajaran Klasifikasi Kladogram Dengan Metode Taksimetri Untuk Mempelajari Kekerabatan Tanaman Genus Tillandsia \& Neoregelia 


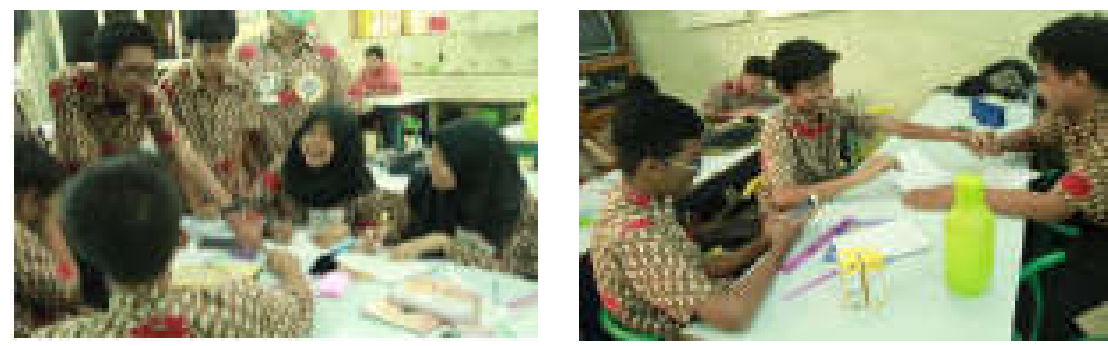

Gambar 11. Siswa memadukan hasil kerjanya dengan teman-temanya

Hasil dari kegiatan penelitian tersebut menunjukkan bahwa kegiatan pengamatan, identifikasi dan klasifikasi tumbuhan kaktus, tillandsia, dan bromilia berlangsung dengan baik. Siswa dengan melakukan kegiatan pengamatan langsung terhadap tanaman-tanaman tersebut dapat mengembangkan kognitif dan antusias siswa seperti hasil penelitian dari Susilo, (2015) dan Schneider, Marrero, Alvarez, \& Presting, (2011) menunjukkan bahwa identifikasi tumbuhan berbiji sebagai materi pembelajaran IPABiologi SMP berbasis potensi lokal memperoleh kategori baik. Setiawan, Wisanti., \& Faizah, (2014) dan Skevington \& Yeates, (2001) juga menyatakan bahwa penggunaan LKS klasifikasi tumbuhan dengan memanfaatkan spesimen awetan dapat melatihkan kegiatan keterampilan proses mengamati, mengklasifikasi, dan mengomunikasikan sehingga peserta didik dapat menemukan sendiri fakta dan konsepnya serta dapat menumbuhkan dan mengembangkan sikap dan nilai yang dituntut.

Siswa dengan melakukan kegiatan dalam penelitian ini juga dapat memperkuat konsep siswa terkait dengan klasifikasi dan kladogram tanaman, sehingga secara tidak langsung siswa dapat memahami ciri-ciri tanaman. Hal tersebut sesuai dengan pendapat Dubois, (2007) serta Sudjana \& Rivai, (2011) adanya spesimen awetan yang digunakan bersama dengan LKS klasifikasi tumbuhan dapat memperkuat konsep peserta didik terkait ciri-ciri berbagai jenis tumbuhan yang terdapat pada divisi Plantae untuk menghindari terjadinya miskonsepsi dan memberikan pengalaman baru bagi peserta didik sehingga peserta didik berperan lebih aktif dalam proses pembelajaran. Pendapat dari Arends, (2008); Chase, (2005); \& Suprijono, (2009) juga menyatakan konsep yang diperoleh peserta didik berupa variasi ciri yang dimiliki oleh masing-masing spesimen tumbuhan dari berbagai divisi yang berbeda meliputi: perawakan, alat reproduksi, dan ada tidaknya berkas pengangkut. Peserta didik mengonstruksi pengetahuannya sendiri melalui interaksi sosial baik secara individu yaitu dengan pengalaman dan objek yang dipelajarinya maupun dengan guru sebagai pembimbing dan teman sebaya dalam kegiatan diskusi.

\section{2) Pembelajaran klasifikasi dan kladogram dengan taksimetri untuk mengidentifikasi dan mendapatkan data jumlah spesies tanaman tillandsia \& neoregelia.}

Kegiatan penelitian ini adalah melakukan pembelajaran klasifikasi kladogram dengan metode taksimetri untuk mempelajari kekerabatan tanaman-tanaman kaktus, Tillandsia, dan Bromilia yang ada di lingkungan SMAN 3 Malang. Tanaman-tanaman yang telah diamati kemudian diklasifikasikan berdasarkan ciri-ciri dari tanaman tersebut. Karakter atau ciri morfologi dari tanaman dapat digunakan untuk membedakan atau mengklasifikasi tanaman-tanaman berdasarkan persamaan dan perbedaan dari tanaman-tanaman tersebut, hal tersebut sesuai dengan hasil penelitian Irawan, Muadz, \& Rosadi, (2013) menunjukkan bahwa karakter atau ciri morfologi dapat digunakan untuk 
membedakan jenis-jenis Rhizophoraceae. Klasifikasi tanaman-tanaman yang ditemukan dapat dilihat pada Tabel 1.

Tabel 1. Klasifikasi Tanaman-Tanaman di SMAN 3 Malang

\begin{tabular}{|c|c|c|}
\hline No & Foto & Deskripsi \\
\hline 1 & & $\begin{array}{l}\text { Kingdom: Plantae } \\
\text { Divisi: Magnoliophyta } \\
\text { Kelas: Liliopsida } \\
\text { Ordo: Bromeliales } \\
\text { Famili: Bromeliaceae } \\
\text { Genus: Tillandsia L. } \\
\text { Spesies: Tillandsia cyanea }\end{array}$ \\
\hline 2 & & $\begin{array}{l}\text { Kingdom: Plantae } \\
\text { Divisi: Magnoliophyta } \\
\text { Kelas: Liliopsida } \\
\text { Ordo: Bromeliales } \\
\text { Famili: Bromeliaceae } \\
\text { Genus: Tillandsia L. } \\
\text { Spesies: Tillandsia lonantha }\end{array}$ \\
\hline 3 & & $\begin{array}{l}\text { Kingdom: Plantae } \\
\text { Divisi: Magnoliophyta } \\
\text { Kelas: Liliopsida } \\
\text { Ordo: Bromeliales } \\
\text { Famili: Bromeliaceae } \\
\text { Genus: Neoregelia } \\
\text { Spesies: Neoregelia spectabilis }\end{array}$ \\
\hline 4 & & $\begin{array}{l}\text { Kingdom: Plantae } \\
\text { Divisi: Magnoliophyta } \\
\text { Kelas: Liliopsida } \\
\text { Ordo: Bromeliales } \\
\text { Famili: Bromeliaceae } \\
\text { Genus: Aechmea } \\
\text { Spesies: Aechmea gamosepala }\end{array}$ \\
\hline
\end{tabular}

Berdasarkan hal tersebut dapat diketahui bahwa lingkungan SMAN 3 Malang memiliki keanekaragaman tanaman kaktus, tillandsia, \& bromilia yang bagus. Beranekaragamnya tanaman tersebut sangatlah cocok untuk membelajarkan pada siswa terkait materi klasifikasi \& kladogram. Penggunaan karakter morfologi dan anatomi memberikan kontribusi yang besar dalam menunjukkan tingkat keragaman dan kemudahan dalam identifikasi. Hal tersebut sesuai dengan pendapat Tellu, (2005) dan Mayr \& Bock, (2008) struktur anatomi \& morfologi merupakan salah satu petunjuk yang dapat digunakan sebagai alat pengidentifikasi jenis atau varietas, mengingat adanya variasi anatomi \& morfologi yang bersifat khas.

Fendy Hardian Permana, Nurwidodo, Lise Chamisijatin, Siti Zaenab, Yuni Pantiwati, Dwi 


\section{3) Pembelajaran klasifikasi dan kladogram dengan taksimetri untuk mempelajari hubungan kekerabatan tanaman tillandsia \& neoregelia.}

Berdasarkan hasil dari klasifikasi Tabel 1, kemudian dibuatlah sebuah kladogram untuk dapat mengetahui hubungan kekerabatan dari tanaman-tanaman tersebut. Kladogram hubungan kekerabatan tanaman-tanaman tersebut dapat dilihat pada Gambar 12.

Kegiatan penelitian ini dalam melakukan klasifikasi tumbuhan di lingkungan SMAN 3 Malang dapat memberikan kontribusi dalam kegiatan klasifikasi tumbuhan modern seperti yang dinyatakan oleh McCarthy, Ridgway, Leseure, \& Fieller, (2000) bahwa penggunaan informasi dari perbandingan anatomi, embriologi, palinologi, sitogenetika, kimia, dan yang lainnya telah memberikan kontribusi yang besar bagi klasifikasi tumbuhan modern. Penelitian ini juga dapat memberikan kontribusi dalam perkembangan taksonomi seperti yang dinyatakan oleh Irawan et al., (2013) bahwa perkembangan taksonomi untuk kepentingan klasifikasi dan filogeni dapat diperoleh dari berbagai sumber, karena seluruh bagian dari tumbuhan pada berbagai tahap perkembangannya dapat menyediakan karakter taksonomi, data harus berasal dari berbagai bidang.

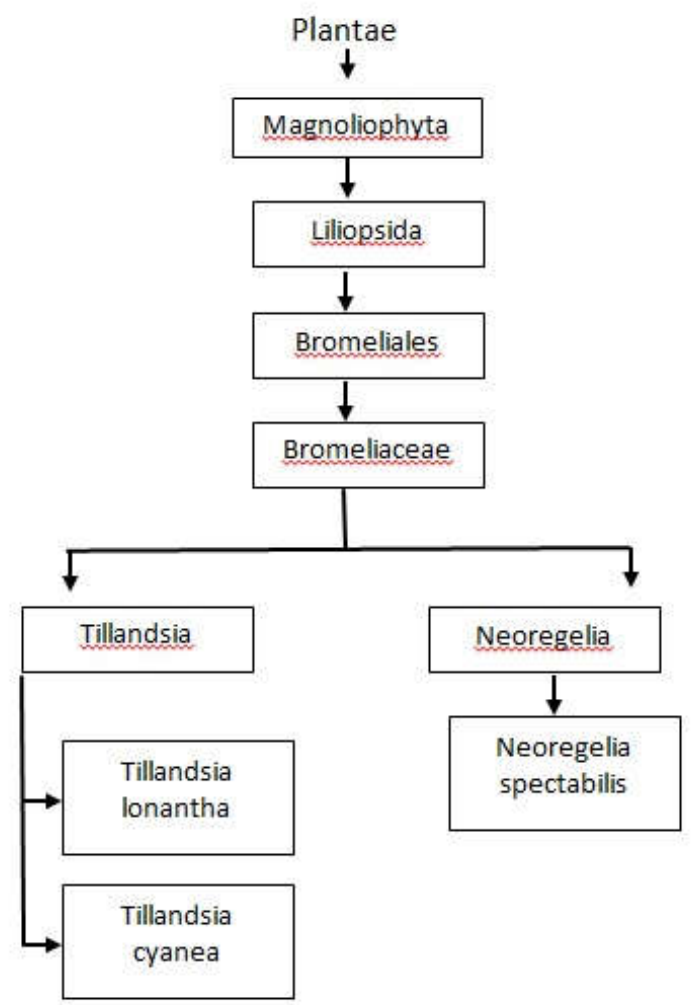

Gambar 12. Kladogram hubungan kekerabatan tanaman

\section{SIMPULAN}

Kesimpulan berdasarkan hasil penelitian ini menunjukkan bahwa melalui pembelajaran klasifikasi kladogram dengan metode taksimetri, diperoleh data sebagai berikut 1) pemanfaatan tanaman dengan ciri morfologi serta persamaan dan perbedaannya menjadi sumber belajar klasifikasi tumbuhan \& pembuatan kladogram berlangsung dengan efektif dimana ditunjukkan dengan siswa terampil dalam melakukan klasifikasi tanaman yang ada di lingkungan sekolah dan terampil dalam 
membuat kladogram dari kegiatan klasifikasi, 2) terdapat 2 spesies tillandsia yaitu Tillandsia lonantha \& Tillandsia cyanea serta terdapat 1 spesies neoregelia yaitu Neoregelia spectabilis, 3) hubungan kekerabatannya tanaman tersebut satu family yaitu Bromeliaceae.

\section{DAFTAR PUSTAKA}

Arends, R. I. (2008). Learning to Teach. Yogyakarta: Pustaka Pelajar.

Arrijani. (2003). Kekerabatan fenetik anggota marga Knema, Horsfieldia, dan Myristicadi Jawa berdasarkan bukti morfologi serbuk Sari. Biodiversitas, 4(2), 8388. doi: https://doi.org/10.13057/biodiv/d040203

Astirin, O. P. (2000). Permasalahan pengelolaan keanekaragaman hayati di Indonesia. Biodiversitas, 1(1), 36-40. doi: https://doi.org/10.13057/biodiv/d010107

Chase, M. W. (2005). Classification of orchidaceae in the age of dna data. Curtis's Botanical Magazine. doi: https://doi.org/10.1111/j.1355-4905.2005.00466.x

Dubois, A. (2007). Naming taxa from cladograms: a cautionary tale. Molecular Phylogenetics and Evolution, 42(2), 317-330. doi: https://doi.org/10.1016/j.ympev.2006.06.007

Irawan, B., Muadz, S., \& Rosadi, A. (2013). Karakterisasi dan kekerabatan tumbuhan mangrove Rhizophoraceae berdasarkan morfologi, anatomi dan struktur luar serbuk sari. Prosiding Seminar Nasional Sains Dan Teknologi Nuklir PTNBRBATAN Bandung. Retrieved from http://digilib.batan.go.id/ppin/katalog/file/18583601-2013-289-297.pdf

Mayr, E., \& Bock, W. J. (2008). Classifications and other ordering systems. Journal of Zoological Systematics and Evolutionary Research, 40(4). doi: https://doi.org/10.1046/j.1439-0469.2002.00211.x

McCarthy, I., Ridgway, K., Leseure, M., \& Fieller, N. (2000). Organisational diversity, evolution and cladistic classifications. Omega, 28(1), 77-95. doi: https://doi.org/10.1016/S0305-0483(99)00030-4

Ramadhani, W. S., Erman, \& Indah, N. K. (2016). Penerapan pembelajaran outdoor learning process (OLP) melalui pemanfaatan taman sekolah sebagai sumber belajar materi klasifikasi tumbuhan untuk meningkatkan hasil belajar siswa SMP. Jurnal Pendidikan Sains, 4(3). Retrieved http://jurnalmahasiswa.unesa.ac.id/index.php/pensa/article/view/ 15312/13870

Schneider, K. L., Marrero, G., Alvarez, A. M., \& Presting, G. G. (2011). Classification of plant associated bacteria using rif, a computationally derived dna marker. PloS One, 6(4). doi: https://doi.org/10.1371/journal.pone.0018496

Setiawan, A. B., Wisanti., \& Faizah, U. (2014). Pengembangan lembar kegiatan siswa klasifikasi tumbuhan dengan memanfaatkan spesimen awetan untuk melatihkan keterampilan proses peserta didik kelas x. Jurnal BioEdu (Berkala Ilmiah Pendidikan Biologi), 3(3). Retrieved http://ejournal.unesa.ac.id/index.php/bioedu

Sihvonen, P., \& Kaila, L. (2004). Phylogeny and tribal classification of Sterrhinae with emphasis on delimiting Scopulini (Lepidoptera: Geometridae). Systematic Entomology, 29(3). doi: https://doi.org/10.1111/j.0307-6970.2004.00248.x

Skevington, J. H., \& Yeates, D. K. (2001). Phylogenetic classification of eudorylini (diptera: pipunculidae). Systematic Entomology, 26(4). doi: https://doi.org/10.1046/j.0307-6970.2001.00160.x

Fendy Hardian Permana, Nurwidodo, Lise Chamisijatin, Siti Zaenab, Yuni Pantiwati, Dwi Sulistiarini, Pembelajaran Klasifikasi Kladogram Dengan Metode Taksimetri Untuk Mempelajari Kekerabatan Tanaman Genus Tillandsia \& Neoregelia 
Sudjana, N., \& Rivai, A. (2011). Media Pengajaran. Jakarta: PT. Sinar Baru Algensindo.

Suprijono, A. (2009). Cooperative Learning: Teori dan Aplikasi PAIKEM. Yogyakarta: Pustaka Pelajar.

Susilo, M. J. (2015). Identifikasi tumbuhan berbiji (Spermatophyta) sebagai materi pembelajaran IPA-Biologi SMP berbasis potensi lokal di kawasan pasir pantai Depok kabupaten Bantul. Prosiding Seminar Nasional Pendidikan Biologi 2015, Yang Diselenggarakan Oleh Prodi Pendidikan Biologi FKIP Universitas Muhammadiyah Malang, Tema:"Peran Biologi Dan Pendidikan Biologi Dalam Menyiapkan Generasi Unggul Dan Berdaya Saing Global. Retrieved from http://research-report.umm.ac.id/index.php/research-report/article/view/489/713

Tellu, A. T. (2005). Kunci identifikasi rotan (Calamus spp.) asal Sulawesi Tengah berdasarkan struktur anatomi batang. Jurnal BIODIVERSITAS, 6(2), 113-117. doi: https://doi.org/10.13057/biodiv/d060209, ISSN: 1412-033X 